\section{Concept of root resection of single rooted teeth: Case report with 8-months follow-up}

\section{Amit Arvind Agrawal*}

Professor, MDS, Periodontics, KBH, MGV Dental College and Hospital, Panchvati, Nasik-422002, Maharashtra, India
Received: 19 December, 2019

Accepted: 20 January, 2020

Published: 21 January, 2020

*Corresponding author: Dr. Amit Arvind Agrawal, MDS, MPhil, Professor, MDS, Periodontics, KBH, MGV Dental College and Hospital, Panchvati, Nasik-422002, Maharashtra, India, Tel: +919822107562; E-mail: agrodent@rediffmail.com

Keywords: Root resection; Fixed partial denture; Single rooted teeth; Root amputation

https://www.peertechz.com

Check for updates

\title{
Abstract
}

Purpose: We have a high percentage of ageing population that is extensively restored. As the number of restorations will increase so will the chances of restoration failure; subsequently their management will become an ever-increasing challenge to the profession. In cases of Fixed Partial Denture (FPD) supported by multiple abutments or Multiple Connected Full-Coverage Restorations (MCFCR); endodontic/periodontal involvement of even a single abutment negatively affects the prognosis of the prosthesis as a whole. Often the decision made by clinician to remove the fixed bridge or MCFCR, extract the tooth in question and make a new FPD is not appreciated by the patient.

Case discussion: This article describes the technique of a root resection in single rooted teeth, gives new information about its application and analyzes the role of this treatment modality in the management of a failing MCFCR.

Conclusion: Resection of root of single rooted teeth which is not acting as terminal abutment in a multiple-connected full coverage restoration was found to be a successful strategy to prolong the success of a fixed prosthesis.

\section{Introduction}

As we approach the millennium, much is spoken about the decline in dental caries and periodontal disease, yet there is a tendency to ignore our aging population with its often extensively restored dentitions. The management of restoration failure will become an ever-increasing challenge to the profession [1]. The patient with a failed restored dentition may present with pain, inability to function, fractured tooth/ root, inflammatory swelling or bleeding gums [2]. Among other factors on which the decision is based, economic potential of the patient is one of the important parameter for treatment planning in countries where dental insurance is yet to come.

In cases of Fixed Partial Denture (FPD), supported by multiple abutments or full coverage restorations that are often connected to provide the benefit of splinting; endodontic/ periodontal involvement of even a single abutment negatively affects the prognosis of the prosthesis as a whole. Often the decision made by clinician to remove the fixed bridge or Multiple Connected Full-Coverage Restorations (MCFCR), extract the tooth in question and make a new FPD is not appreciated by the patient.

Over the years we had been talking about root resection in multirooted teeth [3-5]. This article describes the technique of a root resection in single rooted teeth, gives new information about its application and analyzes the role of this treatment modality in the management of a failing MCFCR.

\section{Case report}

A 52-year-old male patient was referred with a complaint of recurrent swelling, pus discharge and associated pain in mandibular anterior region since 2-years. He had complaint of mobile teeth with 31 and 41 six years back for which he had undergone periodontal therapy followed by Root Canal Treatment (RCT) with teeth 31, 32, 41 and 42 and multiple connected porcelain fuse to metal restorations from teeth 33 to 43 , probably to provide splinting for mobile teeth. He was apparently alright 2-years back when he started experiencing pain and swelling in mandibular anterior region which subsided without any active treatment. Gradually the frequency of pain 
and swelling went on increasing and was then associated with pus discharge.

On examination, deep periodontal pockets were present $(>10 \mathrm{~mm}$ ) with teeth 31 and 41, along with pus discharge (Figure 1A). Radiographic investigations confirmed severe bone loss around teeth 31 and 41 (Figure 1B).

Patient was initially advised removal MCFCR, then extraction of teeth 31 and 41 and fabrication of an FPD but patient was reluctant to this treatment plan. Patient was explained about the root resection procedure and he happily agreed. Under suitable local anesthesia, a full thickness trapezoidal flap was reflected (Figure $2 \mathrm{~A}$ ). With a tapered fissure diamond point the roots of teeth 31 and 41 were resected at a point just apical to the cervical margin of MCFCR and the soft tissue defect was curetted (Figure 2B). The part of the crowns of teeth 31 and 41 that were retained in the restoration, now acts as pontic. The part of this pontic facing the soft tissue was contoured and smoothened with fine diamond point. Since the teeth 31 and 41 were already root canal treated there was no need to prepare pulp chamber and seal with GIC/reinforced resin restoration. Flaps were approximated using 3-0 silk suture (Figure 2C).

Tablet Oflaxacin 200mg, Ornidazole 500mg twice daily for five days and Diclofenac sodium 50mg twice daily for 3-days were prescribed. At follow-up visit 15-days postoperative, the healing was satisfactory. Three months post-operative photograph shows excellent healing and tissue contour (Figure 3A), however there were some soft tissue loss below the prosthesis and slight recession with tooth 42 . At $8^{\text {th }}$ month followup visit, there was excellent healing, the space below the prosthesis has reduced and also a significant root coverage was noted with tooth 42 (Figure $3 \mathrm{~B}$ ). Patient was conveniently and efficiently maintaining the oral hygiene around the bridge without any functional or esthetic complaint.

\section{Discussion}

Root resection has been performed in dentistry since the late 1800 s and is accepted as a valid treatment option with reasonable long-term effectiveness [6-11]. Routine management of MCFCR cases, that involves removing the prosthesis, then treating the tooth/teeth in question and fabricating new prosthesis, may raise certain biological, psychological and financial questions. An additional possibility is that there could be fracture of the crown or trauma to the periodontal ligament of remaining abutments while removing this MCFCR. Secondly, while fabricating a new FPD in that

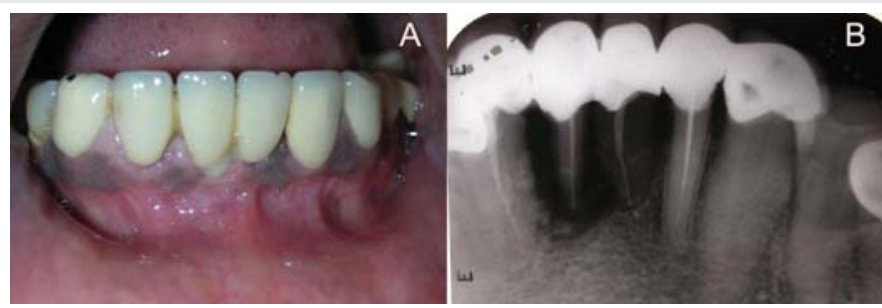

Figure 1: A) Preoperative clinical photograph showing purulent discharge associated with 31 and 41, B) Preoperative radiograph showing root canal treated $31,32,41$ and 42 along with extensive bone loss around 31 and 41.

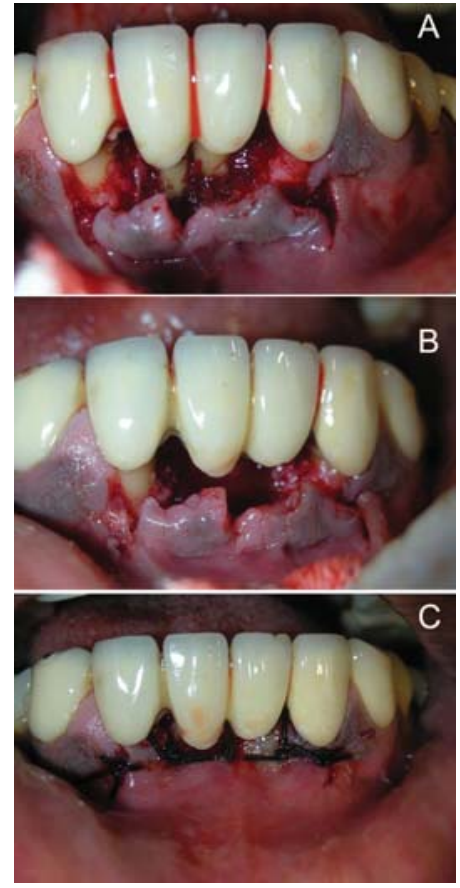

Figure 2: A) Extensive granulation tissue seen associated with roots of teeth 31,41 seen after flap reflection, B) Roots of 31 and 41 resected, crown margins smoothened, and soft tissue wound curetted, C) Flaps approximated using 3-0 mersilk suture.

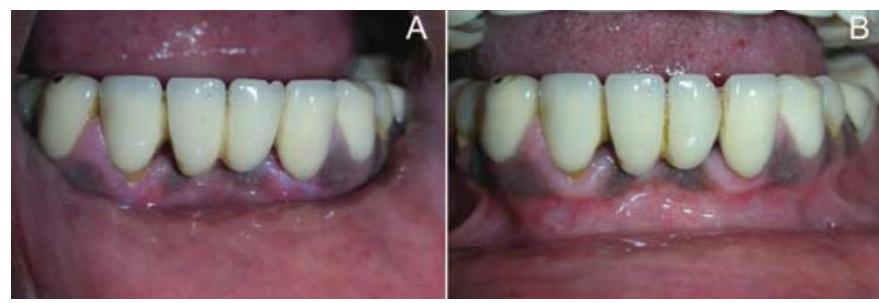

Figure 3: A) Recall followup of 3-months post surgery showing satisfactory healing and good maintenance by the patient, B) 8-months postoperative photograph showing reduced embrasure space, spontaneaous root coverage and chlorhexidine stains.

area, clinician may have to remove additional tooth structure to reshape the abutments. Not to mention the additional extra cost patient will have to bear for the complete treatment along with the cost of new FPD and their time and efforts to get the treatment done.

Success of any root resection procedures depend, to a large extent, on proper case selection. Indications and contraindications reported in the literature apply to root resection in multirooted teeth [4,12]. In addition to those, following are some indication and contraindications for root resection in single rooted teeth.

\section{Indicated when one of the multiple abutments:}

1. Have severe bone loss, which cannot be repaired.

2. When the tooth in question is not a distal terminal abutment in case of FPD supported by multiple abutments.

3. Requires RCT, which cannot be performed without removing the prosthesis. 
4. Unfavorable proximity of roots of adjacent teeth, preventing adequate hygiene maintenance in proximal areas.

5. Have severe root exposure due to dehiscence.

6. Have severe destructive process that may have occurred as a result of sub-gingival caries or traumatic injury.

7. When there is adequate bone support of remaining abutments and removal of root of the tooth in question will not jeopardize the functional component FPD or MCFCR.

\section{Contraindications:}

1. When the risk of removing the root exceeds the benefits of fabricating a new FPD.

2. When an FPD is supported only 2 abutments-Resection of root of one abutment will severely compromise the force distribution.

3. When the tooth is question is a terminal abutmentresection will lead to development of cantilever bridge.

4. When other abutments would not be able to support the bridge after removing the root of tooth in question.

\section{Conclusion}

This technique is not only simple to perform but also has tangible benefits in terms of psychological and financial aspects. There is no report of any documented case of root resection in single rooted teeth in the literature. Although this technique may not be indicated in all cases of failing MCFCR's or FPD's, however within the limits of indications and contraindications, it can definitely be considered as another weapon in the arsenal of the dental surgeon, determined to retain and not remove the fixed prosthesis.

\section{References}

1. Carpendale J (1999) Restoration of the Failing Dentition. J Can Dent Assoc 65 576-578. Link: http://bit.ly/2R7mu3Q

2. Wise MD (1995) Failure in the restored dentition: Management and treatment London: Quintessence Publishing Co. Link: http://bit.ly/2RaFfnd

3. Parmar G, Vashi P (2003) Hemisection: A case-report and review. Endodontology 15: 26-29. Link: http://bit.ly/36fsllZ

4. Weine FS (1996) Endodontic Therapy, $5^{\text {th }}$ edn. St. Louis, USA, CV Mosby. Link: http://bit.ly/37mv0S8

5. Basaraba N (1969) Root Amputation and tooth hemisection. Dent Clin North Am 13: 121-132. Link: http://bit.ly/2uYgP7A

6. Amen C (1966) Hemisection and root amputation. Periodontics 4: 197

7. Hamp S, Nyman S, Lindhe J (1975) Periodontal treatment of multirooted teeth. Results after five years. J Clin Periodontol 2: 126-135. Link: http://bit.ly/2sFxl6h

8. Klavan B (1975) Clinical observations following root amputation in maxillary molar teeth. J Periodontol 46: 1-5. Link: http://bit.ly/2G51ZPd

9. Bergenholtz A (1972) Radectomy of multirooted teeth. J Am Dent Assoc 85: 870-875. Link: http://bit.ly/2NHABLo

10. Erpenstein H (1983) A 3-year study of hemisectioned molars. J Clin Periodonto 10: 1-10. Link: http://bit.ly/2RwBLdl

11. Buhler H (1988) Evaluation of root-resected teeth. Results after 10 years. $J$ Periodontol 59: 805-810. Link: http://bit.ly/369MZKn

12. Minsk L, Polson AM (2006) The role of root resection in the age of dental implants. Compend Contin Educ Dent 27: 384-388. Link: http://bit.ly/2TGAX8S
Discover a bigger Impact and Visibility of your article publication with Peertechz Publications

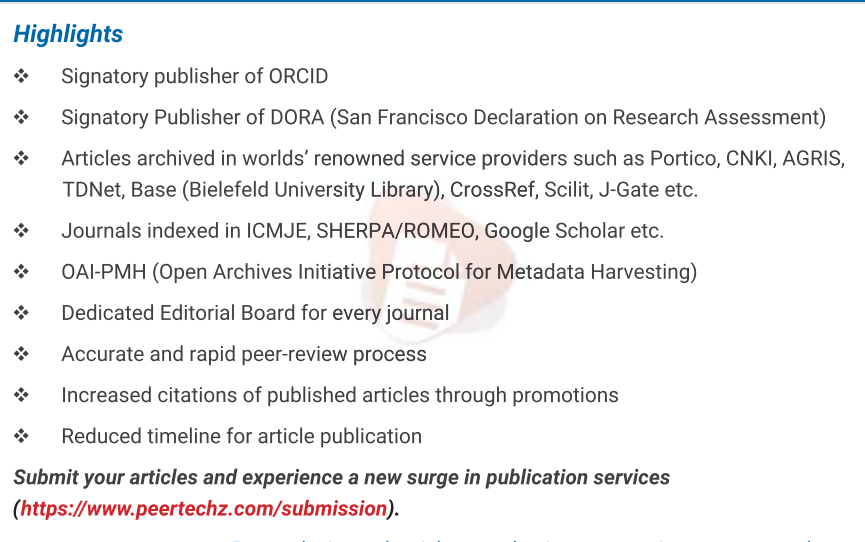

Peertechz journals wishes everlasting success in your every endeavours.

Copyright: @ 2020 Agrawal AA. This is an open-access article distributed under the terms of the Creative Commons Attribution License, which permits unrestricted use distribution, and reproduction in any medium, provided the original author and source are credited. 